\title{
RUSSIAN REVOLUTIONS AND THE PROBLEM OF THE COUNTRY SOCIO-ECONOMIC BACKWARDNESS: THE VIEW OF GERMAN HISTORIANS OF THE TWENTIETH CENTURY
}

\author{
Andrey G. Dorozhkin, Prof. D. of History ${ }^{1}$ Marina N. Potemkina, Prof. D. of History ${ }^{1}$,Maxim V. \\ Popov, Ph.D. ${ }^{1}$,Alexey G. Ivanov, Ph.D. ${ }^{1}$, Svetlana S. Velikanova, Ph.D. ${ }^{1}$, Oksana P. Chernykh, \\ Ph.D. ${ }^{2}$ \\ 1. Nosov Magnitogorsk State Technical University, 38 Lenin Avenue, 455000, Chelyabinsk Region, \\ Magnitogorsk, Russia; \\ 2. Moscow University of Finance and Law MFUA, 17/1 Serpukhov Val str., 115191, Moscow, Russia.
}

\begin{abstract}
The Germanic studies of Russia of the last century showed the interest twice to the problem of economic preconditions for revolutionary events in our country. The first time this interest took place at the beginning of the 20th century, directly in connection with these events. At that, the material quoted by M. Weber and O. Hetch actually doubted the thesis about the probability of a successful bourgeois revolution performance in the Russian Empire, although M. Weber also allowed optimistic sentiments. Such kind of duality is also noticeable among German-speaking scholars studying Russia who addressed the topic in the second half of the 20th century, when there was some interest in it among FRG historians (but not among GDR ones). Most of them, assessed the prospects for imperial modernization in the country skeptically, they did not overestimate the opportunities for a successful implementation of the bourgeois revolution "from below." At that, the specific material that they provided at the end of the 20th century testified to the incompatibility of worker and peasant mentality with bourgeois ideological attitudes. But, given a certain contradictoriness of its position on the issue of "democratic alternatives" to Bolshevism, the German scholars studying Russia during the second half of the 20th century mostly recognized the regularity and naturalness of the Bolsheviks' coming to power.
\end{abstract}

Keywords: backwardness, revolution, modernization, German historiography, Russia, Bolsheviks

\section{INTRODUCTION}

\subsection{Introduction to the problem}

The century of the events since 1917 in Russia has increased the interest to the study and the understanding of these events in general and their economic (as well as social) prerequisites in particular. A deeper interpretation of the issue presupposes a thorough study of its research state, including the research state by foreign historical literature. Here, the analysis of the "Russian" issue coverage by German-speaking countries is also important. Moreover, the problem of the revolutionary event preconditions in our country by German literature of the beginning of the last century was covered even during the events; The sociologist M. Weber and the historian O. Hatch were among the pioneers of this issue study. It should be noted that this article does not analyze the point of view of the former GDR historians - they did not dwell on it in general, unlike their counterparts and opponents from West Germany.

\subsection{Problem relevance}

The problem of backwardness, taking into account the specifics of the revolutionary (or presented as such) events of the twentieth century, is one of the main problems that historians face when they study relevant events. This fully applies to the events of 1905-1907 and 1917 in our country. The issue of backwardness factor role in them, and especially the coming of the Bolsheviks to power, was actively discussed in Soviet historical science since the 1920s. Since the 1960s it was also discussed in Germanic studies of Russia. An appeal to the legacy of the latter will help to present the range of opinions better and more fully on one of the most important issues of Russian and world history of the 20th century, to trace the influence of domestic and foreign historian concepts on each other, to reveal the main trends in the historiography of Russian revolution issue of the 20th century in general.

\subsection{Problem study}


The analytical development of Russian Empire socio-economic backwardness study as the prerequisites for the revolutions of the early 20th century began relatively late. Until the second half of the last century, this issue was covered in Russian literature poorly. In the 1960s V.I. Salov (Salov V.I., 1960. pp. 95-96, 99-100, 102; Salov V.I., 1968. p. 187, 190) turned to the individual aspects of the problem. However, he paid his main attention, to the interpretation criticism the very phenomenon of the October Revolution and its political history by West German historians (to which he attributed the Swiss V. Giterman erroneously). Later, in his article co-authored with V.S. Vasyukov, V.I. Salov analyzed the treatment of West German literature and the economic preconditions of the October Revolution in detail. He also analyzed critically the exaggeration of the scale and significance of the country backwardness as the factor favoring the Bolsheviks' coming to power (Vasyukov V.S., Salov V.I., 1972. pp. 22, 36-37, 39, 43-44, 54). Similarly, the East German historian E. Donnelt criticized the West German historiography of the Bolshevik revolution in Russia (Donnert E., 1966, pp. 164-170).

A more detailed analysis of the West German historiography concerning the problem of the Bolshevik revolution prerequisites in Russia was given by N.I. Kanishcheva (Kanishcheva N.I., 1983; Kanishcheva N.I., 1984). But here the analysis of the relevant plot interpretation by the postwar "Ostforshung" is given without the reference to the review of the problem study by German scholars experienced in "Russia" of the previous periods; Besides, in 1960-1980-ies the Soviet historians, as a rule, confined themselves to the criticism of the interpretation of the economic preconditions of the October Revolution by the West German researchers, rather than the revolutionary events of the early 20th century in general.

Some shift from this approach has been outlined already in the last decade of the twentieth century. R.P. Shpakova paid a close attention to the interpretation of the premises, incl. economic ones, and, in part, to the nature of the revolution of 1905-1907 by famous German sociologist M. Weber (Shpakova R.P., 1997). Later, the analysis of Russia studies of the twentieth century by Germans concerning economic and social prerequisites for Russian revolutions, was considered by one of the authors of this work (Dorozhkin A.G., 2005. pp. 72-80). But the study of pre-revolutionary Russia backwardness as the prerequisite for "great upheavals" as an independent subject of research did not take place. This circumstance determined the choice of the article topic.

\subsection{Hypotheses}

The study of the interpretation of the relationship between the economic and social backwardness of prerevolutionary Russia and the Russian revolutions by German historians of the past century will make it possible to imagine better the development of world studies of Russia in the 20th century, its relationship with domestic historical science, as well as the phenomenon of the revolutionary events of 1905-07 and 1917, originated from the combination of various economic and non-economic factors.

\section{METHODS}

The problem of the backwardness of pre-revolutionary Russia as the prerequisite for the revolutions of 19051907 and 1917 is considered by us in the context of modernization, understood as the process of transition to the industrial society. Revolution is interpreted accordingly. The main part of Germanic scholars studying Russia of the second half of the twentieth century use the modernization approach when the indicated problems were addressed. At the same time, taking into account the author approach of the concepts analyzed by us, the revolutionary events of 1905-1907 and 1917 are taken as a whole while taking into account the specific features of each of the movements, interpreted as a revolution.

In order to study the problem highlighted by German historians of the past century, the scientific principles of historicism, objectivity, comprehensiveness and systemic nature are applied. The work is based on the following general scientific and general historical methods: ideographic, expressed in the description of individual Russian scientist approaches and concepts; the method of periodization, according to which the study of historiography is carried out within a specific period, which makes it possible to analyze the changes of historiographic reality, to identify the beginning of new trends; system, historical-comparative, historical-genetic and historical-typological methods.

\section{MAIN PART}

Submit Date: 14.02. 2018, Acceptance Date: 27.02.2018, DOI NO: 10.7456/1080MSE/113 
In German sociological and journalistic literature, the problem of the social and economic backwardness of the Russian Empire was treated as the most important prerequisite of the revolution, it was addressed at the beginning of the last century, mainly in connection with the events of 1905-1907. M. Weber was the first one who highlighted this problem. The famous sociologist drew his information about Russia, first of all, from journalistic literature and from information communicated to him by the emigrants from Russia (Shpakova R.P., 1997). M. Weber pointed to the absence of a numerous and an authoritative urban middle class of the European type in Russia with the simultaneous ambiguity of the mood and the duality of the position from the petty-bourgeois elements of the city with a good reason. The Russian proletariat shares its sympathies between Christian-social values and socialist theories. A thin stratum of the bourgeoisie does not have the authority to exercise its hegemony in society sufficiently, while it sympathizes with liberalism. At the same time, Weber spoke of Russian business world heterogeneity (Weber, M., 1906. p. 26, 74, 77).

Weber paid a considerable attention to the Russian peasantry and its mentality. Without sharing the populist attitude, he recognized rather far-reaching stratification among this class. M. Weber gave a detailed survey of the communal system that synthesizes the elements of voluntary partnership and forced association (Weber M., 1906. p.27, 80, 85-87, 106-107). He was inclined to regard the mentality of the Russian peasantry as an "archaic communism", fueled by a communal tradition. M. Weber noted that the method of land shortage elimination among direct producers proposed by the liberals, implies not the economic liberation of the village part ready for market relations, but a traditional ethical equation. Thus, speaking objectively, we are not talking about overcoming, but about the strengthening of "archaic communism" (Weber, M., 1906, p. $121,127,129)$.

Nevertheless, M. Weber considered Russia as a European country, while recognizing the specifics of its capitalist evolution. He saw the potential for democratic transformation in the extremely successful zemstvo activities according to his opinion. But contrary to the optimism of the German sociologist, he admitted the indisputable fact that there was no mass base in Russia for a bourgeois-democratic political system. Pointing to the strongest influence of Russia backwardness factors on the nature of the revolutionary movement in it, M. Weber, however, did not raise the question of the possibility to carry out a successful bourgeois revolution in Russia.

At the beginning of the 20th century this issue was given some attention by a prominent Russian history researcher O. Hatch. He drew a particular attention to the imperfection of Russia social structure, especially on the absence of a large, influential and specific burgher cognition in it. Hence, O. Hatch made an objective conclusion about the incompatibility of the 1905 revolution in Russia with the French revolution of the late 18th century (Hoetzsch O. 1917. S. 105). But it seems that it is more legitimate to speak about the absence of not only burgherism in the country, but of the "middle class" of the bourgeois type in general, with a core in the form of economically independent owners of the city and village. As the domestic historian-orientalist L.E. Sklyarov pointed out rightly, only they are able to make up the social support of the bourgeoisdemocratic system (Sklyarov L.E., 1993. p. 130, 166). Obviously, the absence of a given social group in the Russian Empire explains the rapid collapse of the "democratic experiment" in 1917 (if one can speak of it at all) and the transition to the dictatorial type of government.

The conclusions formulated by O.Hetch and especially by M. Weber had a significant impact on the interpretation of the social and economic prerequisites for the revolutionary events of the early 20th century by German historiography of post-war decades. It should be noted that in the relevant works, as in most cases and in domestic ones the events of 1905-1907 and 1917 are estimated as revolutions a priori; The issue of the relationship between reform, revolution and modernization was, for the most part, touched on by German researchers indirectly. A great attention was paid to the interpretation and, in part, to the explanation of the very phenomenon of revolution - for example, T. Schider developed the notion of a "procedural revolution" as a long-term global transformation of all aspects of social life (Schieder T., 1973. S. 16, 23). The researcher of Russia G. Altrichter, who belongs to the "socio-historical direction" among historians, noted the conventionality of revolution class nature (bourgeois, proletarian) and the heterogeneity of their participant composition (Altrichter H., 1997. S. 17-21.). 
In the 1970-ies the West German Russian studies raised the issue of a successful bourgeois revolution possibility in the Russian Empire. K.-H. Shlarp (Schlarp K.-H., 1974. S. 114) paid a special attention to it and gave a negative answer to it due to the underdevelopment of bourgeois relations in the country. In the 1950-ies and 1960-ies, G. Rimsch, B. Meissner, and H. Raupach (Rimscha H. v., 1975, S. 528; Meissner B., 1956, S. 20-22; Raupach H., 1968. S. 8) also paid attention to it. The position by K.H. Schlarp is contradictory one - influenced by Soviet historiography, he argued that the bourgeois-democratic revolution, which should remove the obstacles to capitalist development, was discussed in Russia at the beginning of the 20th century. Continuing the Weberian tradition, he reproduced the contradictoriness of the Weberian point of view on this problem at the same time. In general, the German historians of the second half of the twentieth century gave a negative answer to the issue of a successful bourgeois revolution possibility in prerevolutionary Russia "from below", in fact recognizing the pattern of the Bolsheviks coming to power in 1917. In this regard, they pointed to the weakness of capitalist relations in Russia. Contrary to the point of view expressed by E.Donnert and G.Rimsh, on the one hand, the German-Swiss historian V. Gitterman and T. fon Laue, who is more legitimate in American historiography, were united in the recognition of the liberal-bourgeois system nonviability in the conditions of Russia at the beginning of the twentieth century (Donnert, E., 1966, p. 169. Cf.: Gitermann, V., 1949. S. 15; Rimscha, H. v., 1975. S. 528; Laue T. v. 1956, S. 138-139). Unlike M. Weber, they were focused on the fundamental differences in the historical development of Russia and foreign Europe and, like him, emphasized the weakness and the fragility of Russian capitalism. This opinion was shared by B. Meissner and H. Raupach (Meissner B., 1956, S. 20-22; Raupach H., 1968. S. 8). Yu. Nezold interpreted the objective inevitability of the Bolshevik dictatorship in Russia somewhat differently. In his opinion, the pre-revolutionary Russia attempted to implement a liberal model of social development, but it was associated with S.Yu. Witte's and P.A. Stolypin's policy. However, it turned out to be unsuccessful - despite the successes achieved, the backwardness of Russia from the most developed countries was not eliminated, so the Bolsheviks had to solve this task (Noetzold J., 1966. S. 146-181).

The predominance of the postwar decades of pessimistic assessments in the German literature concerning the possible prospects for the capitalist evolution in tsarist Russia predetermined the explanation of the economic prerequisites for the events of 1905-1917, mainly the backwardness of the country and the objective necessity of its overcoming. This approach is noticeable in the writings of neo-Marxist historians (K.Funken, H. Scherer), and in the works of researchers who did not adhere to Marxist methodology (Funken K., 1976, Scherer H., 1985; Noetzold J., 1966; Geyer D., 1973. S. 120-124, Schlarp K.-H., 1974. S. 104-122). Undoubtedly, the view of tsarism as an obstacle to modernization is contradictory to the supporters of this approach, however, the course of events in Russia after the fall of the monarchy - this fall did not accelerate capitalist development. H. Stoekl describes the situation in the country by the autumn of 1917 as the state of almost complete collapse (Stoekl G., 1974. S. 643-645) and his assessments are consistent with the conclusions of the historians studying Russia, who specifically studied the economic situation in the country of that period (Lorenz R., 1966. S. 368-385, Raupach H., 1968. S. 8). The growth of chaos and "antibourgeois mood" in Russia was also ascertained by G. Altrichter (Altrichter H., 1997. S. 384-385). But the following question is rightful here: is it expedient to relate the Bolshevik revolution of 1917 only with the backwardness of the country, if the bourgeois (or bourgeois-democratic) revolution should put an end to this backwardness theoretically, for which the February coup is often presented? Obviously, the Bolsheviks came to power due to the situation of the eve of October 1917. It seems that it was the inability of the Provisional Government to bring the capitalist transformation of Russia to completion, which meant the cessation (but not the completion) of the capitalist version of the country modernization. In order to resume this process in a different version, the Bolsheviks had to restore the inherited potential of the tsarist regime first of all, the initial base for socialist reconstruction. Consequently, there is every reason to agree with V.I. Bovykin that not only backwardness, but, according to V.I. Lenin, "a certain height of capitalism" was the economic prerequisites for a socialist revolution (Bovykin V.I., 2001. S. 15).

A more balanced approach to the evaluation of the October Revolution preconditions in comparison with the "pessimists" is expressed by H. Haumann, and also by B. Bonech and M. Hildermayer. They recognize both the achievements and the problems of Russia capitalist evolution, and the Bolsheviks coming to power is not derived solely from the backwardness of the country (Handbuch ... Bld.Lfg. 5/6., S. 462-463; Hildermeier M., 1989; Bonwetsch B., 1991). It should be noted that the issue of the relationship between the capitalist transformation of Russia and the prerequisites of the socialist revolution aroused some interest in the German 
political science literature, especially in 1960s-1970s. However, the "pessimistic" approach dominated here. Thus, R. Leventhal, emigrated from Germany to the United States in the 1930-ies, and in 1969 returned to Berlin for teaching and research work at the Free University (in the western part of this city), identified two main types of revolutions. The first of them are represented by the European revolutions of the 16th - 18th centuries, interpreted by him as actually bourgeois revolutions in the Marxist sense, and the second ones are represented by totalitarian movements generated by the elements of stagnation and one-sidedness within the society itself. Although the reference (in full accordance with the "theory of totalitarianism") of fascist movements to "revolutionary" ones and their rapprochement with the communist ones can not but cause objections (Loewenthal R., 1969, S. 71; Schieder T., 1973. S. 18.), R. Levental's treatment of the Bolshevik revolution (he ignores the issue of the events of 1905-1907 and the February of 1917) is of some interest. He notes that, contrary to Marxist theory, the socialist revolution occurred in a backward country, in the absence of mature economic and social prerequisites, the substitute for which was the leadership of the Bolshevik Party (Loewenthal R., 1969. S.74). Thus, the Bolshevik revolution was the prologue to the subsequent revolutions of the twentieth century, which less and less corresponded to the theoretical provisions of Marxism in practice, so that it is possible to speak of a third type of revolution. The Bolsheviks, in spite of a sharply anti-capitalist and partly anti-Western attitude, understood the need for modernization. This required the fragmentary borrowing of foreign experience, mainly in the industrial and technical sphere - here R.Lewenthal (Loewenthal R., 1969, S. 83-84).

The views by R. Leventhal are close to the interpretation of the Russian revolution of the twentieth century preconditions by the historian D. Geyer (Geyer D., 1977. S. 13, 41) and the already mentioned T. Schider. The latter noted that, contrary to Marxist theory, modern revolutions occurred in countries either of "beginning industrialization" (Russia), or with a predominantly agrarian structure (China), or with the system of agrarian monoculture (Cuba). In the latter cases (but not in the Russian version, here there is a shift from the "denationalization" ideas), a significant economic and political dependence on foreign countries was recognized (Schieder T., 1973. S. 44-45).

\section{CONCLUSIONS}

Summing up, it can be stated that German researchers, who applied in the 20th century to the theme of Russian revolutions, considered the socioeconomic backwardness of the country as one of its most important prerequisites. From this factor to the last decade of the twentieth century they derived the success of the Bolshevik coup basically. Here, a certain closeness of their position to the views of Soviet historians of the "new direction" (1960s-1970s) is noticeable in the domestic historiography of the issue. It seems that the weak side of this approach is the underestimation of the progress in the development of capitalist relations achieved by Russia in 1917, a certain lowering of the economic potential accumulated by it and created an objective basis for continuing modernization in other social conditions, i.e. for the success of the socialist revolution precisely, and not a kind of "anti-bourgeois counterrevolution" (Sklyarov LE, 1993, p. 41) with a clearly antimodernization shade, as Leonid Sklyarov put it. Obviously, it is useful to distinguish between the reasons for the mass anti-capitalist attitude that made the Bolsheviks' success in Russia of 1917 possible, and the problem of the economic basis to continue the country modernization in new conditions. Indirectly, this was pointed out by German political scientists of the last third of the twentieth century - R. Leventhal and T. Schider. But they also spoke of Russia economic backwardness as the main reason for the Bolsheviks' success. A somewhat more balanced position was taken in 1980s and 1990s by H. Haumann, M. Hildermayer and B. Bonvech, who recognized both the successes of the capitalist transformation of prerevolutionary Russia, and its difficulties and the fragility of the new relations that take shape in the process of this transformation. In general, however, the German researchers of the twentieth century related the preconditions of the Russian revolutions of the beginning of the last century with the backwardness of the country almost exclusively, and this approach left its imprint on the interpretation of a number of significant issues of economic and social development of pre-revolutionary and Soviet Russia.

\section{REFERENCES}

Bovykin V.I. Financial capital in Russia on the eve of the First World War. Moscow: ROSSPEN, 2001. 320 p. [in Russian].

Vasyukov V.S., Salov V.I. The Great October and its bourgeois interpreters // Criticism of the bourgeois historiography of Soviet society. M., 1972, pp. 14-63. [in Russian]. 
Weber M. Historical essay on the liberation movement in Russia and the position of bourgeois democracy. Trans. from German. Kiev, 1906. 149 p. [in Russian].

Donnert E. The history of pre-revolutionary Russia in the works of modern "Ostforsher" // Criticism of the West German "Ostforshung". Moscow: Nauka, 1966, pp. 151-170. [in Russian].

Dorozhkin A.G. Industrial and agrarian development of pre-revolutionary Russia: the view of Germanspeaking historians of the twentieth century. Moscow-Magnitogorsk, 2004. 351 p. [in Russian].

Kanishcheva N.I. Modern West German bourgeois historiography on the preconditions of the October Revolution // History of the USSR, 1983, No. 4. pp. 160-175. [in Russian].

Kanishcheva N.I. The preconditions of the Great October Socialist Revolution in the coverage of West German bourgeois historiography. The manuscript of the thesis ... from the Cand. of hist. sciences. M., 1984. - 238 p. [in Russian].

Salov V.I. German historiography of the Great October Socialist Revolution. Moscow: Sotsakgiz, 1960. 212 p. [in Russian].

Salov V.I. Modern West German bourgeois historiography. Moscow: Nauka, 1968. 383 p. [in Russian].

Sklyarov L.E. Iran of 60-80-ies: traditionalism against modernity. Moscow: Nauka, 1993. 255 p. [in Russian].

Shpakova R.P. Max Weber on democratic reforms in Russia at the beginning of the twentieth century. // Max Weber, read today. St. Petersburg, 1997, pp. 137-145. [in Russian].

Altrichter H. Russland 1917. Ein Land auf der Suche nach sich selbst. Paderborn: Schoeningh, 1997. 604 S. [in German].

Bonwetsch B. Die russische Revolution 1917: eine Sozialgeschichte von Bauernbefreiung 1861 bis zum Oktoberumsturz. Darmstadt: Wiss. Buchges., 1991. 240 S. [in German].

Funken K. Die oekonomischen Voraussetzungen der Oktoberrevolution. Zur Entwicklung des Kapitalismus in Russland. Frankfurt a. Main-Zurich, 1976. 372 S. [in German].

Geyer D. Der russische Imperialismus. Studien ueber Zusammenhang von innerer und auswaertiger Politik. 1860-1914. Goettingen, 1977, S. 13, 41. [in German].

Gitermann V. Geschichte Russlands. Bd. 3. Zuerich, 1949. 679 S. [in German].

Handbuch der Geschichte Russlands. Bd. 3. Lfg. 5 /6. Stuttgart, 1982. [in German].

Hildermeier M. Die russische Revolution 1905 - 1921. Frankfurt a.M.: Suhrkamp, 1989. 350 S. [in German].

Hoetzsch O. Russland. Eine Einfuehrung auf Grund seiner Geschichte vom japanischen bis zum Weltkrieg. Berlin: Reimer, 1917. 439 S. [in German].

Laue T. v. Die Revolution von aussen als erste Phase der russischen Revolution 1917 // Jahrbuecher fuer Geschichte Osteuropas (JGO), 1956, Bd. 4, H. 2, S. 138-139 [in German].

Lorenz R. Zur Industriepolitik der provisorischen Regierung // JGO, 1966, Bd. 14, H. 3, S. 368-385; Haumann H. Kapitalismus, S. 157-165. [in German].

Loewenthal R. Unvernunft und Revolution. Ueber die Losloesung der revolutionaeren Praxis von der marxistischen Theorie // Monat, 1969, № 251, S. 71-87. [in German].

Meissner B. Sowjetrussland zwischen Revolution und Restauration. Koeln, 1956. 231 S. [in German].

Noetzold J. Wirtschaftspolitische Alternativen der Entwicklung Russlands in der Aera Witte und Stolypin.

Berlin (W), 1966. 217 S. [in German].

Raupach H. Geschichte der Sowjetwirtschaft. Reinbek bei Hamburg, 1968. 261 S. [in German].

Rimscha H.v. Gescichte Russlands. Darmstadt: Wiss. Buch., 1975. 694 S. [in German].

Scherer H. Der Aufbruch aus der Mangelgesellschaft. Die Industrialisierung Russlands unter dem Zarismus (1860 bis 1914). Giessen: Focus, 1985. 350 S. [in German].

Schieder Th. Theorie der Revolution // Revolution und Gesellschaft. Theorie und Praxis der Systemveraenderung. Freiburg-Basel, 1973, S. 13-45. [in German].

Schlarp K.H. Revolution und okonomische Ruckstandigkeit. Die russische Revolution als Modellfall // Ansichten der kunftigen Geschichtswissenschaft. Munchen, 1974. Bd. 2, S. 103-128. [in German].

Stoekl G. Russische Geschichte von den Anfaengen bis zur Gegenwart. Stuttgart, 1973. 888 S. [in German]. 